\title{
Absorption and Theatricality
}



ABSORPTION AND THEATRICALITY

Painting and Bebolder in the Age of Diderot

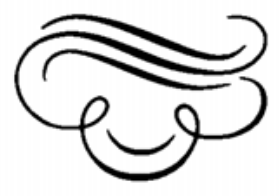

\section{MICHAEL FRIED}

UNIVERSITY OF CALIFORNIA PRESS Berkeley - Los Angeles • London 
Library of Congress Cataloging in Publication Data

Fried, Michael

Absorption and theatricality.

Includes index.

1. Painting, French. 2. Painting, Modern-

17th-18th centuries-France. I. Title.

ND546.F73 $759.4 \quad 78-62843$

ISBN 0-520-03758-8

University of California Press

Berkeley and Los Angeles, California

University of California Press, Ltd.

London, England

ำ 1980 by

The Regents of the University of California

Printed in the United States of America

$\begin{array}{lllllllll}1 & 2 & 3 & 4 & 5 & 6 & 7 & 8 & 9\end{array}$ 
TO RUTH 
